H.J. Manson MB CHB FFarCS FRCP(C), G. Dyke MD FRCP(C), J. Melling B MedSei, M. Gough MB CHB FFARCS

\section{The Effect of Naloxone and Morphine on Convulsions in Mice Following With- drawal from Nitrous Oxide}

Nitrous oxide analgesia is reversed by naloxone, ${ }^{1-4}$ and nitrous oxide, like morphine, produces an increase in mouse locomotor activity which can be reduced by naloxone. ${ }^{5}$ It may be that increased levels of endogenous opiates, produced by nitrous oxide exposure, play a part in these phenomena. ${ }^{2,5}$

It has recently been shown that mice will convulse if stimulated soon after withdrawal from an atmosphere containing nitrous oxide. ${ }^{6,7}$ It is suggested that this represents an acute withdrawal syndrome. ${ }^{6,7}$ If so, it is of interest to determine whether endogenous opiates are involved.

We have therefore examined whether prior treatment with naloxone or morphine affects the incidence of withdrawal convulsions following nitrous oxide exposure.

\section{Materials and Methods}

Male ICR mice (CD-1) weighing between 35 and 45 grams were kept in a standard animal care environment with 12 hours of daylight per day and were given Purina mouse chow and water ad libitum. All experiments were carried out at the same time of day. The mice were exposed either to a test environment of 70 per cent nitrous oxide with 30 per cent oxygen or a control environment of 70 per cent nitrogen with 30 per cent oxygen for 30 minutes. Composition of the environment was confirmed by an independent observer using a Beckman LB-2 analyser for nitrous oxide and a Beckman E2 oxygen analyser.

In the initial series (A), 20 mice in each environment were given, by subcutaneous injection, either 
(1) naloxone $0.125 \mathrm{mg}$ in $0.5 \mathrm{ml}$ normal saline, (2) normal saline $0.5 \mathrm{ml}$, or (3) morphine $0.4 \mathrm{mg}$ in 0.5 $\mathrm{ml}$ normal saline.

To confirm the results of the initial series and to look at a dose response curve for naloxone, a further series of mice (B) were treated in the same way with the addition of two groups of mice given naloxone $0.25 \mathrm{mg}$ in $0.5 \mathrm{ml}$ and $0.5 \mathrm{mg}$ in $0.5 \mathrm{ml}$ respectively. Once again, all groups contained 20 mice.

All mice received the test solutions five minutes prior to removal from the nitrous oxide or control atmosphere.

Fifteen minutes after removal from the nitrous oxide or control atmosphere, mice were tested for convulsions by gently lifting them by the tail for six seconds. Presence of facial grimacing, ears pointing forward, forepaw crossing and violent shaking was scored as a convulsion. ${ }^{8}$ To standardize the stimulation applied, no attempt was made to spin the mice if a convulsion was not elicited.

All mice were scored by the same observer, who was unaware of which test solution had been injected, or which controlled environment was being used. The results of the naloxone and morphine groups were compared with the saline control group for both nitrous oxide and control atmospheres. There were 20 mice in each treatment group, tested individually for convulsion. The proportion convulsing for all tests was used to calculate the variance $=\sqrt[V]{p(1-p) / n=}$ $V(0.61(0.39) / 80=5.5$ for two treatments of 40 mice, total, in each. The averages were compared with Dunnett's critical value (Owen, 1962: table $4.4)^{9}$ for two sided multiple comparisons at 95 per cent confidence.

\section{Results}

The results of the tests are shown in Table 1.

The mice exposed to the nitrous oxide environment showed a significantly higher incidence of convulsions when given naloxone $0.125 \mathrm{mg}$ and $0.25 \mathrm{mg}(\mathrm{p}<0.05)$ as compared to the saline control, There were slightly more convulsions in the naloxone $0.5 \mathrm{mg}$ group than in the saline control group but the difference was not significant.

Mice exposed to nitrous oxide given morphine $0.4 \mathrm{mg}$ showed a significantly lower incidence of convulsions as compared to the saline controls ( $\mathrm{p}<$ 0.05 ).

The average percentage of mice convulsing after
TABLE I Proportion of Mice Convulsing after Treatmenl with Morphine, Saline, or Naloxone

\begin{tabular}{llll}
\hline & \multicolumn{2}{l}{ Proporion Convulsing } \\
\cline { 2 - 4 } $\begin{array}{l}\text { Treatment } \\
\text { Dose) }\end{array}$ & Group $1^{*}$ & Group 2* & Total \\
\hline $\begin{array}{l}\text { Saline 0.9\% } \\
(0.5 \mathrm{cc})\end{array}$ & 0.60 & 0.50 & 0.55 \\
$\begin{array}{l}\text { Naloxone } \\
(0.125 \mathrm{mg})\end{array}$ & 0.80 & 0.65 & $0.73 \dagger$ \\
$\begin{array}{l}\text { Naloxone } \\
(0.25 \mathrm{mg})\end{array}$ & - & 0.80 & $0.80 \dagger$ \\
$\begin{array}{l}\text { Naloxone } \\
(0.5 \mathrm{mg})\end{array}$ & - & 0.60 & 0.60 \\
$\begin{array}{l}\text { Morphise } \\
(0.4 \mathrm{mg})\end{array}$ & 0.45 & 0.30 & $0.38 \dagger$ \\
\hline
\end{tabular}

*Proportions convul sing between groups not significantly different $(\mathrm{p}>0.05)$

†Significantly $(p<0.01)$ different from saline $(=$ control $)$.

nitrous oxide exposure in the control group was 55 per cent.

No convulsions were observed in any of the groups exposed to the control environment of oxygen and nitrogen.

No convulsions were observed during injection of any of the test solutions.

The proportion convulsing was slightly and consistently lower in group 2 but analysis by Dunnett's critical value test revealed that this was not significant $(p>0.05$ ) for any of the groups.

\section{Discussion}

Our results for the saline groups exposed to nitrous oxide are in agreement with those of Harper et al. ${ }^{7}$ who reported a 50 per cent rate of withdrawal convulsions following 30 minutes' exposure to 70 per cent nitrous oxide, using the same criteria for convulsions. We observed no convulsions in any group exposed to the nitrogen-oxygen atmosphere, and no convulsions on picking up and injecting the mice while still exposed to the nitrous oxide atmosphere. This tends to confirm that the convulsions are related to nitrous oxide withdrawal, We have found that more convulsions occur on testing 15 minutes after withdrawal from nitrous oxide in mice given $0.125 \mathrm{mg}$ and $0.25 \mathrm{mg}$ of naloxone than in control animals given an equal volume of saline. The frequency of convulsions appears to be doserelated for the two lower doses tested; it is surprising that the result seen with naloxone $0.5 \mathrm{mg}$ was not significant. It may be that this is due to opiate 
agonist action of naloxone at the higher dose $^{10}$ or to non-specific effects of high doses of naloxone at other sites. $^{10}$

Morphine, on the other hand, significantly decreased the incidence of convulsions in our experiment. This might suggest that nitrous oxide exposure leads to increased levels of endogenous opiates (as already proposed ${ }^{2,5}$ ), and that susceptibility to convulsions is a feature of falling endogenous opiate levels, exacerbated by moderately high doses of naloxone and diminished by exogenous opiate. Our results do not appear to agree well with those of Milne et al." who found no increased frequency of withdrawal convulsions following comparable doses of naloxone. However, there are several differences in methodology, making comparison difficult.

Milne et al. gave naloxone after removal from the test atmosphere; we gave the test substances before withdrawal. They used different nitrous oxide levels and a much longer exposure.

We scored only classes III-IV of Goldstein's convulsion scale ${ }^{8}$ to avoid undue subjectivity and to permit comparison of our results with those of Harper et al. ${ }^{7}$ Milne's group scored all classes, finding some degree of convulsions in all the mice exposed to nitrous oxide and calculating a severity score.

We only tested for convulsions at 15 minutes after withdrawal. If changing endogenous opiate levels are the causative mechanism, we felt that this short period would be compatible with the known half-life ${ }^{12}$ of these substances. Milne et al. tested up to six hours post-withdrawal and overall found no significant effect.

We gave our test substances subcutaneously and not intraperitoneally as Milne et al. did, since we feared that hepatic elimination of part of the naloxone might affect serum levels. ${ }^{13}$

Clearly these apparently differing results and our puzzling result at the highest naloxone dose level point to the need for further work. It may be important to find out exactly which points of methodology are involved in determining the outcome. It may also be useful to attempt to construct a detailed dose-response curve for naloxone.

We conclude that endogenous opiate systems may be involved in the nitrous oxide withdrawal syndrome seen. It is tempting to speculate that it is falling endogenous opiate levels, following their increase during nitrous oxide exposure, which precipitates the convulsions. High doses of naloxone are involved, which should make us cautious in accepting this hypothesis, however, since there is some question over the specificity of naloxone at high dose levels. On the other hand the fact that morphine also has an effect makes it more likely that the opiate receptors are involved.

It is also possible that opiates and naloxone play an indirect role in preventing or facilitating the convulsions.

\section{Acknowledgement}

We wish to thank David G. Bryant, $\mathrm{PhD}$, of the Division of Community Medicine, Memorial University of Newfoundland for his statistical assistance.

\section{References}

1 Berkowitz $B A, N g a i S H$, Finck $A D$. Nitrous oxide 'analgesia': resemblance to opiate action. Sciences 1976; 194; 967-8.

2 Berkowitz BA, Finck AD, Ngai SH. Nitrous oxide analgesia: reversal by naloxone and development of tolerance. J Pharm Exp Ther 1977; 203: 539-46.

3 Chapman $C R_{1}$ Benedetti $C$. Nitrous oxide effects on cerebral evoked potential to pain. Anesthesiology 1979; 51: 135-8.

4 Yang, JC, Clark WC, Ngai SH. Antagonism of nitrous oxide analgesia by naloxone in man. Anesthesiology 1980; 52: 414-17

5 Hyses $M D$, Berkowitz $B A$. Nitrous oxide stimulation of locomotor activity: Evidence for an opiatelike behavioural effect. J Pharm Exp Ther 1979; 209: 304-8.

6 Smith RA, Winter PM, Smith $M$ et al. Convulsions in mice after anesthesia. Anesthesiology 1979; 50: 501-4.

7 Harper MH, Winter PM, Johnson BH, Koblin DD, Eger $E I$. Withdrawal convulsions in mice following nitrous oxide. Anesth Analg 1979; 59: 19-21.

8 Goldstein DB, Pal N. Alcohol dependence produced in mice by inhalation of ethanol: Grading the withdrawal reaction. Science 1971; 172: 288-90

9 Owen DB. Handbook of Statistical Tables, Table 4.4. Addison-Wesley Publishing Co. Inc. , Reading, Mass., 1962.

10 Sawynok J, Pinsky C, LaBella FS. Minireview on the Specificity of Nalox one as an Opiate Antagonist. Life Scjences 1979; 25: 16-21. 
11 Milne B, Cervenko FW, Jhamandas KH. Physical dependence on nitrous oxide in mice: Resemblance to alcohol but not to opiate withdrawal. Can Anaesth Soc J $1981 ; 28: 46-50$.

12 Loh $H H, T_{\text {seng }} L F$, Wei E, $\mathrm{LiCH}$. $\beta$-endorphin is a potent analgesic agent, Proc Natl Acad Sci 1976; 73 2895-8.

13 Weinstein $S H$, Pfeffer $M$, Schor SM, Franklin $L$, Mintz $M$, Tutko ER. Absorption and distribution of naloxone in rats after oral and intravenous administration. J Pharm Sc 1973; 62: 1416-19.

\section{Résumé}

La fréquence des convulsions a été déterminée chez les souris aprés la séparation de l'aunosphère de 70 pour cent de protoxyde d'azote. Des groupes de vingt souris ont reçu une solution saline (les contrôles), de la naloxone ou de la morphine en injections souscutanées cinq minutes avant la séparation. L'observateur n' Était pas au courant du mode de traitement. En comparaison avec le groupe contrôle, la proportion des souris convulsives augmenta de façon significative ( $p<0.05$ ) apres l'injection de naloxone $0.125 \mathrm{mg}$ ( $\mathrm{n}$ à $40,0.25 \mathrm{mg}$, mais non pas $0.5 \mathrm{mg}$. La fréquence significative des convulsions baissa aver l'injection de morphine $0.5 \mathrm{mg}$. La proportion globale des souris convulsives était 0.55 pour celies injectées de solution saline (le groupe contrôle); 0.73 avec la naloxone $0.125 \mathrm{mg} ; 0.80$ avec la naloxone à $0.25 \mathrm{mg} ; 0.60$ avec la naloxone à $0.50 \mathrm{mg}$ et 0.38 avec la morphine dे $0.4 \mathrm{mg}$. La modification de ce phénomene des suites d'un opiate antagoniste et agoniste suggère l' élimination de l'endorphine comme agent possible. Cepen. dant, on se gardera d'évaluer cette évidence comme directe en attendant de plus amples recherches dans ce domaine. 